\title{
Understanding and Managing Sepsis in Patients With Cancer in the Era of Antimicrobial Resistance
}

\author{
Carlota Gudiol ${ }^{1,2,3 *}$, Adaia Albasanz-Puig ${ }^{1,3}$, Guillermo Cuervo ${ }^{1,3}$ and Jordi Carratalà ${ }^{1,3}$ \\ ${ }^{1}$ Infectious Diseases Department, Bellvitge University Hospital, Bellvitge Biomedical Research Institute (IDIBELL), University \\ of Barcelona, Barcelona, Spain, ${ }^{2}$ Institut Català d'Oncologia (ICO), Hospital Duran i Reynals, Bellvitge Biomedical Research \\ Institute (IDIBELL), Barcelona, Spain, ${ }^{3}$ Spanish Network for Research in Infectious Diseases (REIPI RD16/0016/0001), \\ Instituto de Salud Carlos III, Madrid, Spain
}

Sepsis is a frequent complication in immunosuppressed cancer patients and hematopoietic stem cell transplant recipients that is associated with high morbidity and mortality rates. The worldwide emergence of antimicrobial resistance is of special concern in this population because any delay in starting adequate empirical antibiotic therapy can lead to poor outcomes. In this review, we aim to address: (1) the mechanisms involved in the development of sepsis and septic shock in these patients; (2) the risk factors associated with a worse prognosis; (3) the impact of adequate initial empirical antibiotic therapy given the current era of widespread antimicrobial resistance; and (4) the optimal management of sepsis, including adequate and early source control of infection, optimized antibiotic use based on the pharmacokinetic and pharmacodynamics changes in these patients, and the role of the new available antibiotics.

Keywords: sepsis, septic shock, cancer, bacteremia, bloodstream infection, neutropenia, antibiotic resistance

\section{INTRODUCTION}

Sepsis is defined as a life-threatening organ dysfunction caused by a dysregulated host response to infection. It is associated with significant morbidity and mortality $(1-3)$ that increase markedly when septic shock becomes established. Moreover, sepsis and septic shock are major healthcare problems, affecting millions of people worldwide each year, with the increasing cost of sepsisassociated medical care now estimated at $\$ 17$ billion annually in the United States (4). Given the rapidly expanding elderly population with their associated immune senescence and frailty (5), the mortality rates associated with sepsis are expected to increase dramatically over the next 2 decades (6).

The epidemiology of sepsis in industrialized countries is mainly influenced by the age of the population and the increasing prevalence of comorbidities, such as chronic organ dysfunctions, non-cancer-related immunosuppressive diseases, or cancer itself. Patients with cancer are at more than ten times higher risk for sepsis than the general population, with some variability according to the cancer types $(7,8)$. Mortality due to sepsis has decreased over time in these patients, probably due to improvements in the general management of sepsis, advances in cancer therapies, and improvements in the intensive care unit (ICU) admission policies. Nevertheless, in recent decades, we are facing the alarming emergence of antimicrobial resistance among microorganisms that cause infection and sepsis, in both the general population and the immunosuppressed alike, which can negatively influence outcomes (9). Of special concern is the widespread emergence and dissemination of multidrug-resistant (MDR) Gram-negative bacilli (GNB), which are a common cause of infection and sepsis in patients with cancer. Several investigators have reported high rates 
of bacteremia due to extended-spectrum $\beta$-lactamase (ESBL)producing Enterobacterales (10-13), MDR Pseudomonas aeruginosa (MDR-PA) (12, 14-17), and carbapenem-resistant Enterobacterales (CRE) (18-22), among others, against which there are few treatment alternatives. This is of paramount importance because inadequate initial empirical antibiotic therapy can increase mortality when patients with cancer have infection due to MDR-GNB (11, 13-16, 18-23). Therefore, in the current era of widespread antibacterial resistance, there is an urgent need for the development of new agents with activity against MDR-GNB. In the meantime, novel $\beta$-lactam/ßlactamase inhibitors may be safe and effective options for treating infections due to some of these $\operatorname{MDR}-\mathrm{GNB}(24,25)$. In addition, specific strategies may help improve the overall prognosis of immunosuppressed patients with cancer, such as rapidly identifying sepsis (e.g., scores and biomarkers), optimizing ß-lactam antibiotic use (e.g., extended infusions), and optimizing source control and providing aggressive management in the ICU.

Finally, the pathophysiology of sepsis in the presence of cancer is especially complex because both entities share pathophysiological characteristics that result from the incapacity of the host's immune system to deal with an initial trigger. Thus, a dysregulated immune system seems common to both scenarios, raising the specter of their mutual impact on each other's course. Improving our knowledge about this bidirectional interaction between sepsis and cancer may lead to future research possibilities that could help modulate the dysfunctional immune system and the hyperinflammatory state, thereby improving sepsis control.

In this review, we aim to assess the prevalence, characteristics, etiology, and outcomes of sepsis in immunocompromised cancer patients and hematopoietic stem cell transplant (HSCT) recipients and to gain knowledge regarding the physiopathology of sepsis in these contexts. We also aim to review optimal management in the current era of widespread antimicrobial resistance. Finally, we will briefly comment on the current gaps in the literature and on directions for future research. Our focus is on sepsis due to bacterial infection. This review was not designed to provide evidence-qualified recommendations.

\section{SEARCH STRATEGY AND SELECTION CRITERIA}

We searched PubMed/MEDLINE for articles that were published from January 2000 to October 2020, using the following terms: "sepsis," "severe sepsis," "septic shock," "pathophysiology," "immunosuppression," "cancer," "solid tumor," "hematologic malignancy," "hematopoietic stem cell transplant," "neutropenia," "bacteremia," "bloodstream infection," "intensive care unit," "antibiotic resistance," "multidrug resistance," "mortality," "SOFA," "procalcitonin," “C-reactive protein," "adrenomedullin," "ceftolozane/tazobactam," “ceftazidime/avibactam," and "extended infusion." Articles resulting from these searches, together with any relevant references cited in those articles, were reviewed. We only included articles written in English and involving adult patients.

\section{THE BURDEN OF SEPSIS IN CANCER PATIENTS}

Some years ago, Angus et al. reported that one in 6 patients with sepsis presented a malignant underlying disease and that these patients suffered $30 \%$ excess mortality than other patients with sepsis (26). More recent ICU observational series have confirmed that about $15-20 \%$ of patients admitted to critical units have hematologic or solid malignancies (27-30), with sepsis being a leading cause of ICU admission in these patients $(31,32)$. Nevertheless, sepsis-associated mortality in cancer patients has decreased over recent decades (33-36), probably due to advances in sepsis diagnosis and management, cancer therapies, and ICU admission policies (37-39).

The current rates of in-hospital mortality of cancer patients presenting with sepsis and septic shock are $\sim 20$ and $40 \%$, respectively (36). Sepsis-related mortality relies on not only appropriate early management of multiple organ failure but also minimizing prolonged ICU stays and associated complications (40, 41). Moreover, the long-term outcome of cancer sepsis survivors after ICU admission is depended on the prognostic determinants of the underlying diseases as well as the possibility of continuing antineoplastic treatment, which may be hampered by loss of functional status and/or persistent organ dysfunction (42-45). Importantly, since early sepsis mortality has decreased over time, attention has recently been paid to late mortality after recovery from sepsis. Even though the exact causes of long-term sepsis mortality are still unclear, some investigations suggest that older age, comorbidities, and persistent organ injury are detrimental and lead to the immune system's dysfunction and suppression, with persistent inflammation and catabolism $(46,47)$.

The increased risk of sepsis in cancer patients is due to several factors: immunosuppression caused by the underlying disease, the specific onco-hematological treatments causing immunosuppression, and the invasive procedures used (e.g., long-term central venous catheters, urinary catheters, drainages, etc.). However, the cancer population is heterogeneous and there is great variation in the degree of immunosuppression. Hematological patients are at highest risk of infection and sepsis, particularly those with acute leukemia who often present prolonged and profound neutropenia $(36,48,49)$, historically one of the most important risk factors for sepsis and mortality $(50,51)$.

Multiple myeloma and HSCT also place patients at higher risk of sepsis compared with other hematological malignancies (36, 40). HSCT recipients represent a unique population that is severely immunosuppressed due to the underlying disorder, the conditioning regimen, and the treatment of complications, such as graft-vs. host-disease (GVHD). In this setting, allogeneic transplant recipients presenting with GVHD seem to be at higher risk of sepsis and death compared to non-HSCT recipients and both autologous and allogeneic patients without GVHD, reaching mortality rates as high as 55\% (52). Among patients with solid tumors, the most sepsis occurs with lung or gastrointestinal cancers, followed by other subtypes depending on the series. 
In patients with solid malignancies, the site of primary or metastatic tumor often serves as the portal of entry $(36,48,53,54)$.

Even though febrile neutropenia (FN) is a frequent complication, occurring in $20-30 \%$ of patients with solid tumors and $80 \%$ of patients with hematological malignancies receiving chemotherapy, only $20-30 \%$ will develop bacteremia. Therefore, the rate of sepsis and septic shock globally is relatively low for FN. In line with this, a recent Brazilian study evaluating the frequency and epidemiology of early death and shock in 1,305 episodes of FN in 826 hematologic patients collected from 2003 to 2017 found that shock occurred in 42 (3.2\%) on the first day of FN and early death occurred in $1.1 \%$ (55). In this study, predictors of septic shock were bacteremia due to Escherichia coli [odds ratio (OR), 8.47; 95\% CI 4.08-17.55; $p<0.001$ ), Enterobacter sp. (OR, 7.53; 95\% CI 1.60-35.33; $p=0.01$ ), and Acinetobacter sp. (OR, 6.95; 95\% CI 1.49-32.36; $p=0.01$ ).

\section{PATHOPHYSIOLOGY OF SEPSIS IN CANCER PATIENTS}

\section{Sepsis-Related Immunosuppression}

Sepsis is an extremely complicated process in which several situations may occur and lead to a persistent immunosuppression and hyperinflammation. On the one hand, it induces a severe state of immunosuppression that affects both cellular effectors of the innate and adaptative immune systems, changes that can persist even after recovery $(56,57)$. These comprise functionally essential cells, such as neutrophils, monocytes and macrophages, natural killer (NK) cells, dendritic cells, B lymphocytes, and $\mathrm{T}$ lymphocytes (including gamma delta $\mathrm{T}$ cells, $\mathrm{T}_{\mathrm{H}}$ cell subpopulations and regulatory $\mathrm{T}$ cells). On the other hand, sepsis induces a state of complex immune dysfunction, including hyperinflammation (excessive release of inflammatory cytokines IL-1, TNF, and IL-7) (58), homeostatic dysfunction (59), complement activation, fibrinolytic and clotting system stimulation (60), redox imbalance (causing severe oxidative stress) (61), mitochondrial dysfunction (62), and molecular alterations (causing organ damage) (56).

\section{Cancer-Related Immunosuppression}

The immunosuppression in cancer that increases the risk of infection and sepsis is mainly associated with specific onco-hematological therapies that impair the immune system. Treatment with chemotherapy and radiotherapy alters the phagocytic activity of neutrophils and monocytes by depleting their circulating counts and impairing their capacity for chemotaxis and phagocytosis (63). As mentioned above, the risk of infection and sepsis is strongly associated with the depth and duration of neutropenia and monocytopenia $(51,52)$. Most cytostatics induce quantitative and/or functional modifications in lymphocytes and NK cells, while other anti-lymphoproliferative drugs and monoclonal antibodies (e.g., fludarabine, bendamustine, ibrutinib, rituximab, and alemtuzumab) can induce prolonged B- and/or T-cell lymphopenia (64). Corticosteroid use is also frequent in cancer patients, increasing the degree of immunosuppression. They cause both a pleiotropic dysregulation of innate and adaptive immune responses and a decrease in the activities of neutrophils, monocytes, macrophages, and lymphocytes (mainly $\mathrm{CD}^{+}{ }^{+} \mathrm{T}$ cells). At high doses, they also induce apoptosis, decrease IL-2 levels, and impair the Th2-cell response. Therapy with HSCT may delay immune reconstitution due to persistent lymphopenia, low cell diversity, and defective lymphocyte functions (65). In addition, chemotherapy and radiotherapy may impair other organ and tissue functions, limiting their capacity to deal with the initial aggression. In this regard, it has been suggested that the endothelial toxicity secondary to cytostatic agents may lead to microcirculatory alterations and an impaired vessel response to vasopressors (66).

There are specific cancer settings that may increase the risk of infection and sepsis, regardless of antineoplastic therapy. The involvement of the bone marrow and/or the presence of dysmyelopoiesis by certain hematological malignancies or by metastatic solid tumors may lead to important cytopenias and/or defective phagocytic activity of neutrophils and monocytes (67). Some lymphoproliferative disorders may also cause hypogammaglobulinemia, and the compression of anatomic structures and/or tissue infiltration by malignant cells can diminish local defense mechanisms.

Finally, tumor cells can escape cytotoxic cells by losing major histocompatibility class-1 molecules, leading to the inappropriate expression of checkpoint inhibitory molecules, and can exhibit functional defects that result in decreased antigen presentation, and altered dendritic, macrophage, NK, and CD8 T cell function (68). Whether tumor-related immune alterations increase the risk of infection still needs to be confirmed.

\section{The Bidirectional Interaction Between Cancer and Sepsis}

There are pathophysiological similarities between cancer and sepsis that favor the interaction between these two processes. Indeed, some malignancy-related conditions and adverse drug reactions can mimic sepsis (69) and may hinder differentiation between these entities. In particular, certain aggressive hematological diseases, such as acute leukemia and highgrade B-cell lymphoma may present multiple organ dysfunctions through several pathways, such as tissue infiltration by tumor cells, anatomical compression, intracellular metabolite release, altered coagulation, and hemophagocytic lymphohistiocytosis $(70,71)$. Currently available antineoplastic therapies, including T-cell based therapies (e.g., bispecific monoclonal antibodies and chimeric antigen receptor- $\mathrm{T}$ cells) or differentiating agents (e.g., all-trans retinoic arsenic or acid), may also produce acute systemic inflammatory syndromes that mimic sepsis $(72,73)$. Differentiating these entities is of paramount importance because managing these proinflammatory conditions varies significantly.

The similarities between cancer-related and sepsis-induced immune dysfunctions indicate that immune defects derived from infectious triggers may facilitate a favorable environment and promote tumor growth. Consistent epidemiological and experimental findings support a link between sepsis and further risk of cancer (74-77). Conversely, some historical reports and experimental studies have suggested that sepsis may instead have antitumoral activity $(78,79)$, with "cancer-then-sepsis" models suggesting that sepsis may induce tumor suppression (80-82). 
Interestingly, recent data also suggest that antibiotic-induced dysbiosis (changes in the composition and diversity of gut microbiota) may alter the immune response to cancer $(83,84)$. Finally, it has been hypothesized that certain Toll-like receptors could have a role in modulating tumor growth in sepsis $(85,86)$.

\section{CHARACTERISTICS, ETIOLOGY, AND OUTCOMES OF SEPSIS IN CANCER PATIENTS}

There are several current studies evaluating the prevalence, clinical features, etiology, and outcomes of cancer patients with bacteremia, with reported rates of septic shock varying by series from 6 to $57 \%(11,13,15,18-20)$. Nevertheless, very few investigations have focused on patients presenting with sepsis or septic shock $(31,36,48,49,52,55,87,88)$, and among these, some were retrospective, some used different sepsis definitions, and some did not provide comprehensive data. Table 1 summarizes the most relevant data for cancer patients with sepsis or septic shock.

Overall, patients with hematological malignancies, mainly acute leukemia, are at greatest risk of sepsis $(36,48,49)$. Patients with multiple myeloma $(36,48,87)$ and non-Hodgkin lymphoma $(31,36,55,87)$ also seem to experience high rates of sepsis and septic shock. HSCT recipients have been included in only few series, but rates of sepsis range from 3 (87) to $12 \%$ (36), as reported in a recent large study of cancer with 2,062 patients admitted to seven European ICUs for sepsis or septic shock. In this study, data were extracted from the Groupe de Recherche Respiratoire en Réanimation OncoHématologique database, from 2006 to 2010. Patients more often had hematological $(82.4 \%)$ than solid $(17.6 \%)$ malignancies, and many $(31 \%)$ had neutropenia at ICU admission. The 30-day mortality rate was $39.9 \%$ and decreased significantly over the study period [odds ratio (OR) 0.96; 95\% CI, 0.93-0.98; $p=0.001$ ].

Seeking to characterize the frequency and outcomes of sepsis in adult HSCT recipients and to compare them to non-transplant patients, Kumar et al. retrospectively analyzed a large nationwide administrative database from almost $20 \%$ of the community hospitals in the United States (52). Data were provided separately according to the reason for admission (engraftment admission or subsequent admission with and without GVHD). Of the 291,179 discharges with HSCT between 2000 and 2008, sepsis was identified in $21,898(7.5 \%)$. The frequency of sepsis was 5 times higher in HSCT recipients than in non-transplant patients. Allogeneic transplant recipients and those with GVHD (10.4\%) had significantly higher rates of sepsis than either autologous recipients $(13.2$ vs. $5.2 \%$; $p<0.001)$ or those without GVHD (10.4 vs. 6.1\%; $p<0.001$ ). The unadjusted hospitalrelated mortality was significantly higher among allogeneic transplant recipients than non-HSCT recipients (55.1 vs. $32.9 \%$, $p<0.001$ ), but the mortality rates did not differ between autologous HSCT recipients and the non-transplant population. After adjustment, however, the odds of mortality were 3.81 times higher in allogeneic HSCT recipients (95\% CI, 2.39-6.07) and 1.28 times higher in autologous recipients compared with non-transplant patients (95\% CI, 1.06-1.53). Table 2 displays more detailed information on the engraftment admissions and compares patients according to the type of transplant.

Among solid tumors, the rates of sepsis vary by the series, with gastrointestinal $(31,87)$ and lung cancers (48) being most susceptible. In a recent report of 1,009 patients with gynecological cancers receiving 10.239 cycles of chemotherapy, the incidence of septic shock during neutropenia was $3 \%$ and the mortality rate was $1.2 \%$ (88). The incidence of septic shock during neutropenia was also higher in patients older than 50 years (3.9 vs. $1.4 \%$, $p=0.034$ ), with a linear-by-linear association between the accumulated cycles of chemotherapy and the sepsis rate $(p=$ $0.004)$. Also, patients who had received two or more courses of chemotherapy presented and increased incidence of neutropenic septic shock (NSS) compared with those receiving only one course ( 4.9 vs. $1.4 \%, p=0.002)$. No significant differences were observed regarding the type of gynecological cancers and the status of the disease between patients with NSS and patients without NSS. The mortality rate of patients with NSS was $37.5 \%$. In this study, the median age (64.0 vs. $56.5, p=0.017)$ and the peak heart rate (149.5 vs. $\left.123.5 \mathrm{~min}^{-1}, p=0.015\right)$ were significantly higher in the group of patients who subsequently died of NSS than in those who survived.

In $\sim 30-50 \%$ of the sepsis and septic shock episodes occurring in patients with cancer, no microbiological diagnosis is achieved $(31,87)$. When a definitive microbiological diagnosis is made, blood cultures are the most useful tool because most episodes are secondary to bacteremia and/or high-inoculum infections, such as pneumonia, with frequent secondary dissemination to the bloodstream.

The site of infection is barely provided in the few series addressing sepsis in cancer patients. In a report addressing shock and early death in hematologic patients with FN, Rosolem et al. described the site of infection in 563 cases of sepsis (91\% with septic shock) admitted in the ICU (31). The most frequent sites were the lung (44\%), the abdomen (31\%), and the urinary tract (8\%), with 24 patients (4\%) having more than one site. GNB were responsible for more than $50 \%$ of episodes, with E. coli (16\%), P. aeruginosa (13\%), and Klebsiella pneumoniae (13\%) being most common. The overall ICU and hospital-related mortality were 51 and $65 \%$, respectively; these were higher in patients with septic shock (62 and 74\%) than in patients with either sepsis (36 and 55\%) or sepsis (15 and $25 \%)$. Mortality rates were higher for patients with pneumonia and bacteremia than with gastrointestinal and urinary tract infections. End-of-life decisions were made for $29 \%$ of patients in their cohort.

In a subgroup analysis of a multicenter prospective cohort study in 28 Brazilian ICUs, 717 patients with cancer were analyzed (87). Among them, 37\% had sepsis and 53\% septic shock. The most frequent infection sites were the lungs (48\%), abdomen (19\%), bloodstream (primary) (19\%), and urinary tract (17\%). Half had a microbiologically confirmed infection, with GNB again being the most frequent cause (31\%). ICU- and hospital-related mortality rates were 42 and $56 \%$, respectively. End-of-life decisions were made in $17 \%$ of the patients. 
TABLE 1 | Summary of the most relevant series of cancer patients presenting with sepsis and septic shock.

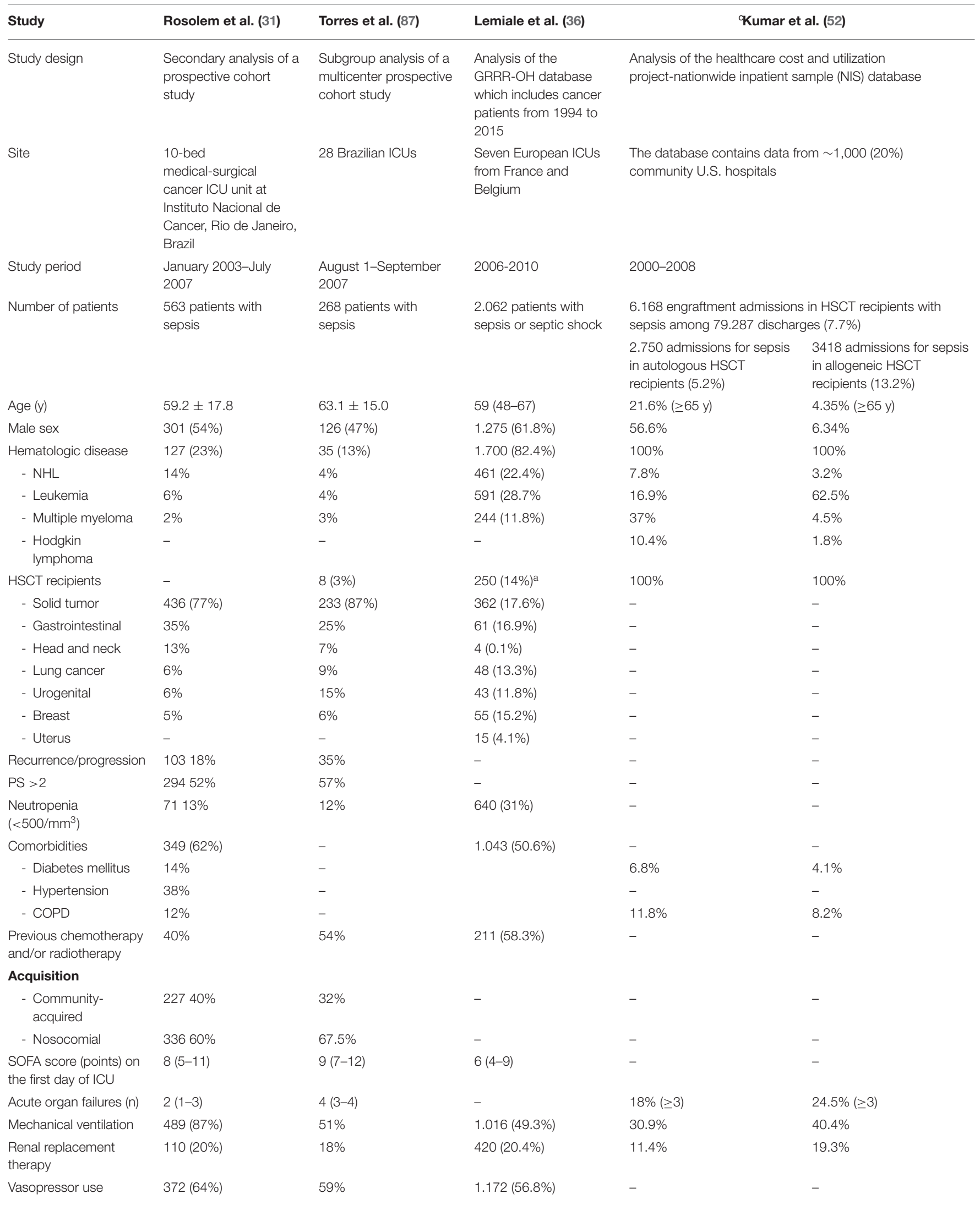


TABLE 1 | Continued

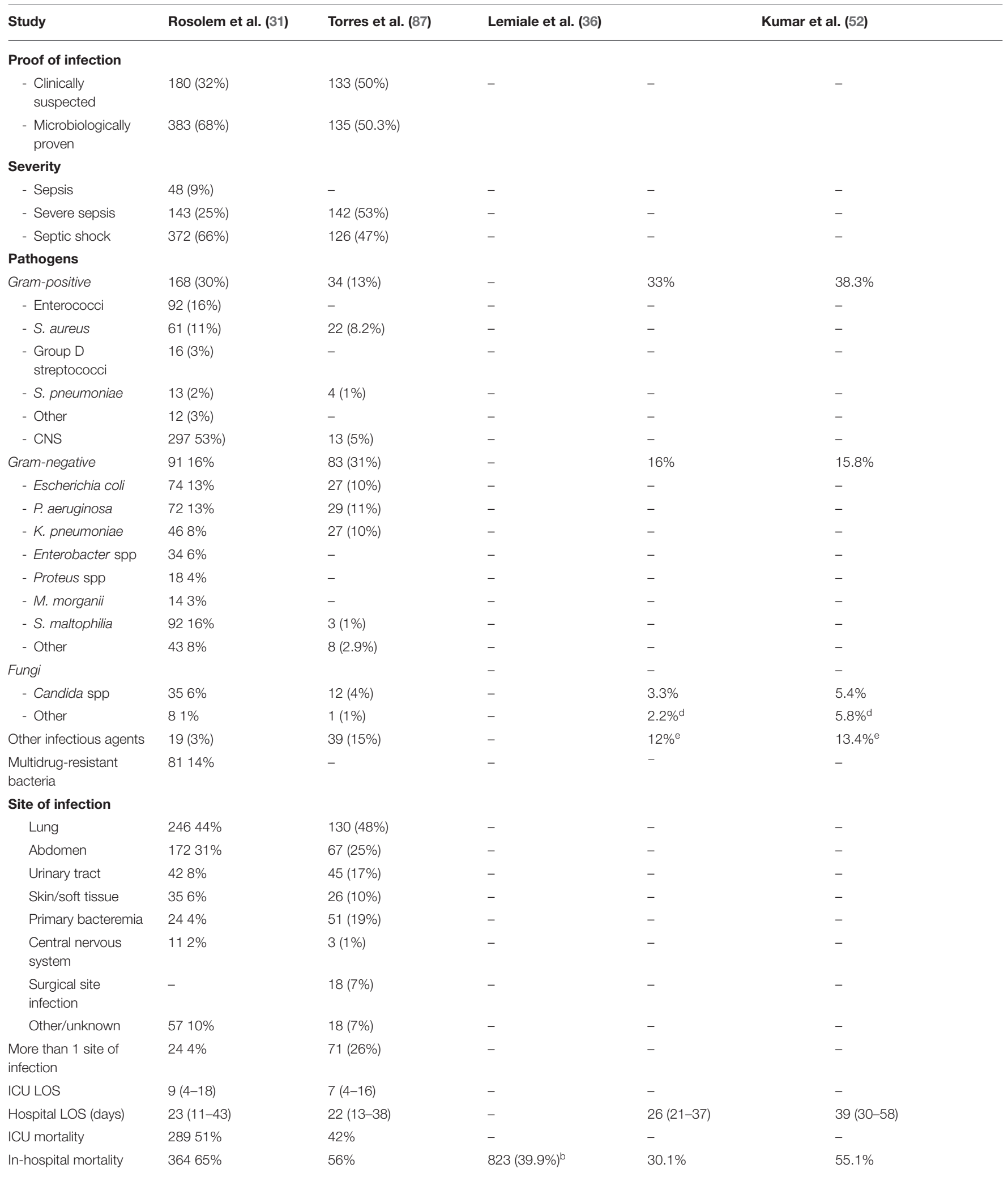

NHL, Non-Hodgkin lymphoma; HSCT, hematopoietic stem cell transplant; COPD, chronic obstructive pulmonary disease; SOFA, Sequential Organ Failure Assessment; ICU, Intensive care unit; CNS, Coagulase-negative staphylococci; LOS, Length of hospital stay; GRRR-OH, Groupe de Recherché Respiratoire en Réanimation Onco-Hématologique.

${ }^{a}$ Only data on allogeneic HSCT were provided; ' ${ }^{b}$ Data on 30-day mortality were available in 943 patients (45.7\%), approximated using hospital mortality in 879 patients (42.6\%) and as last resort ICU mortality if the former were unavailable; ' Only data regarding engraftment admission are provided in this table. Data on subsequent admissions in HSCT recipients with and without graft-vs. host diseases are provided in the complete version of the manuscript. ${ }^{d}$ Infections due to Aspergillus spp.; ${ }^{e}$ Clostridioides difficile colitis. 
TABLE 2 | Risk factors associated with mortality in the most relevant series of sepsis and septic shock in cancer patients.

\begin{tabular}{|c|c|c|c|c|c|}
\hline References & Patients studied & Outcome & & OR $(95 \% \mathrm{Cl})$ & $\boldsymbol{P}$ \\
\hline \multirow[t]{9}{*}{ Rosolem et al. (31) } & 563 cancer patients with sepsis & In-hospital mortality & Admission to a medical ICU & $2.19(1.40-3.42)$ & 0.001 \\
\hline & & & Active-newly diagnosed disease & $1.76(1.12-2.75)$ & 0.013 \\
\hline & & & Active-recurrence/progression & $2.42(1.35-4.35)$ & 0.003 \\
\hline & & & Performance status $>2$ & $3.57(2.36-5.979)$ & $<0.001$ \\
\hline & & & Non urinary tract infection & $3.28(1.57-6.86)$ & 0.002 \\
\hline & & & SIRS criteria $\geq 3$ & $1.80(1.20-2.72)$ & 0.014 \\
\hline & & & Cardiovascular dysfunction & $1.94(1.27-2.94)$ & 0.008 \\
\hline & & & Respiratory dysfunction & $2.29(1.24-4.23)$ & 0.002 \\
\hline & & & Renal dysfunction & $2.12(1.34-3.35)$ & 0.001 \\
\hline \multirow[t]{4}{*}{ Torres et al. (87) } & 268 cancer patients with sepsis & In-hospital mortality & Organ dysfunction & $1.48(1.16-1.87)$ & 0.001 \\
\hline & & & Hematological malignancy & $2.57(1.05-6.27)$ & 0.038 \\
\hline & & & Performance status $>2$ & $2.53(1.44-4.43)$ & 0.001 \\
\hline & & & Polymicrobial infections & $3.74(1.52-9.21)$ & 0.004 \\
\hline \multirow[t]{2}{*}{ Lemiale et al. (36) } & 2.062 cancer patients with & 30-day mortality & Mechanical ventilation & $3.25(2.52-4.19)$ & $<0.01$ \\
\hline & sepsis or septic shock & & Vasopressor use & $1.42(1.10-1.83)$ & $<0.01$ \\
\hline \multirow[t]{10}{*}{ a Kumar et al. (52) } & 6.168 engraftment admissions in & Unadjusted in-hospital & Allogeneic HSCT & $2.12(1.55-2.90)$ & NA \\
\hline & HSCT recipients with sepsis & mortality & Age 35-49 years & $1.68(1.08-2.60)$ & NA \\
\hline & & & Age $\geq 65$ years & $2.08(1.13-3.83)$ & NA \\
\hline & & & Cirrhosis as comorbidity & $4.49(1.81-11.1)$ & NA \\
\hline & & & Multiple myeloma & $0.59(0.40-0.89)$ & NA \\
\hline & & & Respiratory failure & $12.1(8.64-16.8)$ & NA \\
\hline & & & Cardiac failure & $2.42(1.59-3.66)$ & NA \\
\hline & & & Renal failure & $2.64(1.95-3.56)$ & NA \\
\hline & & & Metabolic failure & $1.63(1.07-2.49)$ & NA \\
\hline & & & Hepatic failure & $5.22(2.29-11.8)$ & NA \\
\hline
\end{tabular}

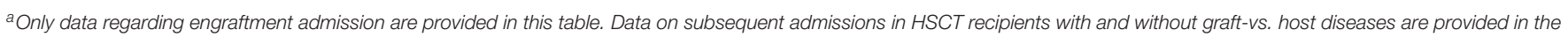
complete version of the manuscript.

\section{RISK FACTORS FOR MORTALITY IN CANCER PATIENTS WITH SEPSIS AND SEPTIC SHOCK}

Table 2 shows the risk factors associated with mortality for the most relevant series of patients with cancer who developed sepsis or septic shock. The most commonly variables associated with mortality are those related to the underlying disease (mainly hematological malignancies) $(52,87)$ and its status (uncontrolled cancer and poor performance status) $(31,87)$, the presence of one or more organ dysfunctions $(31,52,87)$, and the need for organ support (36). Some other variables identified as risk factors for mortality include older age $(52,88)$, comorbidities (52), infection site (particularly pneumonia) (31), polymicrobial infection (87). Of note, the year of ICU admission has also been shown to influence cancer patient's outcomes significantly, with decreased mortality rates observed over time $(36,52)$. The nutritional status of cancer patients may also play an important role in the development of sepsis and on its outcomes. In this regard, a study conducted in our institution involving head and neck cancer patients (who are particularly malnourished) with bacteremia identified hypoalbuminemia as independent risk factor for bacteremia and for early and overall mortality (89). Importantly, inadequate initial empirical antibiotic therapy (IEAT) is widely recognized as an important risk factor for mortality in all patients, including those with immunosuppression due to cancer $(14,18,23,90-92)$. Kadri et al. recently published a retrospective cohort analysis of electronic health record data from 131 hospitals in the US that included 21,608 patients with bacteremia who received empirical antibiotics between 2005 and 2014 (93). Among them, 4,165 (19\%) received IEAT, which was independently associated with increased mortality (adjusted OR 1.46; 95\% CI, 1.28-1.66); $p<0.0001$ ), regardless of whether sepsis or septic shock was present. Infection due to antibioticresistant organisms was strongly associated with an increased risk of receiving IEAT (adjusted OR 9.09; 95\% CI 7.68-10.76; $p<$ $0.0001)$.

Several studies have shown that cancer patients with infections due to resistant pathogens are more likely to receive IEAT (90-92). In addition, many of these studies have shown that failure to cover resistant organisms, and particularly MDR-GNB, significantly and independently impairs their outcomes (10, 11, $14,18,20,22,23)$. The presence of septic shock and/or the need for ICU admission have also frequently been identified as risk factors for mortality in cancer patients with bacteremia (94). Therefore, it is reasonable to hypothesize that these factors (IEAT and sepsis/septic shock) synergize to affect the prognosis of these patients negatively. However, there remains no firm 
evidence of how IEAT impairs outcomes in cancer patients with sepsis.

\section{OPTIMAL MANAGEMENT OF SEPSIS IN CANCER PATIENTS}

\section{Early Recognition and Diagnosis}

In 2017, Rhodes et al. published the "Surviving Sepsis Campaign," which are international guidelines for the management of adult patients with sepsis and septic shock. These guidelines provide the best evidence-based recommendations for the management of this life-threatening condition (95).

Several studies in the general population have demonstrated that the Sequential Organ Failure Assessment (SOFA) score better predicts hospital mortality for ICU patients with infection compared with the systemic inflammatory response syndrome. Therefore, a new definition of sepsis and septic shock was adopted in 2016 (1), and later studies have demonstrated that the new definitions are applicable to cancer with the same reliability as in the general population (94). In addition, the quickSOFA (qSOFA), constitutes a simple bedside clinical score that can be rapidly applied and allows the prompt identification of patients at greatest risk of need for admission to an intensive care unit. The qSOFA score is based in 3 simple variables, which include respiratory rate $\geq 22 / \mathrm{min}$, alteration in mental status, and systolic blood pressure $\leq 100 \mathrm{~mm} \mathrm{Hg}$ (96). The SOFA and qSOFA scores are therefore useful tools to identify and predict complications and mortality in these patients (97-99), and as such, should be applied to all cancer patients with suspected infection.

In recent decades, over 180 biomarkers have been evaluated as unsuitable for the diagnosis and prognosis of sepsis, being lactate one of the most frequently used (100). To date, none have demonstrated sufficient specificity or sensitivity for reasonable utility in clinical practice. Procalcitonin (PCT) and C-reactive protein (CRP) have perhaps been the most widely used, but they have limited ability to distinguish sepsis from other inflammatory conditions or to predict outcomes. More recently, elevated serum lactate has been used as a biomarker in the diagnosis of septic shock (1). There is also interest in the role of these biomarkers as diagnostic, prognostic, and theragnostic markers in febrile cancer patients, particularly those with FN. Despite the paucity of data about biomarkers in cancer patients, some reports have evaluated their role. In this regard, PCT has been shown to have better accuracy than CRP and IL-6 in differentiating infectious from non-infectious causes of fever in a meta-analysis of 27 studies in adult and pediatric cohorts (101). However, this meta-analysis included different types of underlying disease and evaluated different outcomes. Several other reports have shown that PCT can predict bacteremia in cancer patients with and without neutropenia, particularly those with infection by GNB, and that it may predict a need for organ support (102-106).

Adrenomedullin (ADM) is also elevated in sepsis, which results in pro-ADM that is present at higher levels in patients with localized infections and bacteremia than in healthy controls (107). Pro-ADM has shown to be more suggestive of sepsis than PCT in cancer patients (108), and its levels are more significantly elevated in patients with hematological cancers and localized infections than in those with no infections (108). Nevertheless, another study of critically ill cancer patient revealed that pro$\mathrm{ADM}$ and PCT had similar areas under the roc curve for identifying bacteremia, both being superior to that of CRP (109). Other biomarkers, such as presepsin, IL-6, and IL-8, appear to be less useful (110). The role the currently available biomarkers in cancer patients with sepsis clearly needs to be elucidated further.

\section{Antibiotic Therapy}

In the current era of growing antimicrobial resistance, the following general considerations need to be assessed before deciding on empirical antibiotic therapy in cancer patients (particularly in FN): prior history of colonization/infection with resistant pathogens; the presence of other risk factors for antibiotic resistance; the local epidemiology and resistance patterns in that hospital, unit, and geographical area; and other patient-related factors that may predict a complicated clinical course (e.g., older age, comorbidities, localized infection, and shock).

After this evaluation, cancer patients with sepsis or septic shock need urgent therapy with a broad-spectrum antipseudomonal BLA with or without other agents that are active both against the suspected organisms and at the site of infection (111). It remains controversial whether adding a short-course aminoglycoside to a broad-spectrum BLA regimen can benefit severely ill patients. An important meta-analysis (112), as well as a recent prospective observational cohort study of 648 ICU patients (113), failed to show this association. In the study by Ong et al. there was no association with a faster reversal of shock or an increased 14-day survival; however, that study mainly included immunocompetent patients, and only $4 \%$ received IEAT, probably due to low local levels of antibiotic resistance (113).

Interestingly, in a previously published study we observed improved early (7- and 14-day) mortality rates in those who received initial combination therapy, who also presented more frequently with septic shock. In a prospective study of 510 hospitalized patients with bacteremia in the context of neutropenia due to hematological malignancy, we also observed better 30-day survival in those who received combination therapy (94). Similar findings have been reported in the general population by other investigators $(114,115)$. Therefore, while awaiting the results of well-designed randomized clinical trials, we advocate the inclusion of short-course aminoglycoside therapy with a BLA for IEAT when treating neutropenic cancer patients in centers with a high prevalence of multidrug resistance, especially if sepsis or septic shock are present.

The empirical use of the two novel antibiotics, ceftolozane/tazobactam and ceftazidime/avibactam, should be considered in cancer patients at risk of infection due to MDR-GNB (e.g., MDR-PA, CRE, or ESBL-Enterobacterales), particularly if they present with sepsis or septic shock. Targeted therapy with these agents should be also considered if other first-line antibiotics are not viable treatment options because of a lack of activity or a high-risk of toxicity. Although these novel antibiotics have not been specifically approved for neutropenic and/or cancer patients, they are being used in these setting due to the increasing problem of antibacterial resistance among 
GNB. These drugs have been used in real-world settings, where they are reported to show clinical and microbiological success in high-risk hematological patients. However, there is a scarcity of data, and where it is present, it is based mainly on case series and case reports (116-122). Table 3 summarizes the main clinical and microbiological data in these studies.

An alternative strategy for the treatment of infections due to resistant GNB organisms is to use existing BLAs by extended or continuous infusion to maximize their pharmacokinetic (PK) activity (123). Critically ill patients present certain physiopathologic changes, mainly due to an increased volume of distribution and an increased renal clearance, making them excellent targets for this strategy. In fact, two meta-analyses have shown an association between prolonged BLA infusions and lower mortality rates in critically ill patients $(124,125)$. Cancer patients with FN may be considered similar to critically ill patients in terms of the intra- and inter-individual variability of PK parameters (126-128).

Regarding the clinical impact of optimizing the use of BLAs, data are limited for neutropenic patients and restricted to certain antibiotics $(129,130)$. A recent single-center randomized clinical trial found that extended infusion with a BLA was associated with superior outcomes than intermittent infusion, the greatest benefit observable in patients with pneumonia (131). Nevertheless, that study had some methodological limitations, and there were no PK studies to support the clinical results (132). Currently, a multicenter, open label, randomized, superiority clinical trial is being performed (EudraCT 2018-001476-37, ClinicalTrials.gov: NCT04233996) to assess the clinical efficacy of extended BLA infusions in hematological patients with neutropenia. Other secondary outcomes include PK/pharmacodynamic target achievement, bacteremia clearance, CRP decrease, overall 30-day case-fatality rate, and adverse events. Finally, a population PK model of the BLA studied will be developed (133).

In the current era of emerging antimicrobial resistance, antimicrobial stewardship is of paramount importance in order to decrease the overall antimicrobial consumption and hinder resistance dissemination. In this regard, the last guidelines recommend applying antimicrobial stewardship strategies in patients with sepsis and septic shock, such as de-escalation and/or discontinuation of antibiotic within the first few days in response to clinical improvement and infection resolution and/or lack of evidence of infection (95). Cancer patients with sepsis and septic shock can be probably managed in the same way. In this line, we recently published a randomized clinical trial involving high-risk hematologic patients with febrile neutropenia without microbiologically documented infection, in which we demonstrated that empirical antibiotic therapy can be discontinued after $72 \mathrm{~h}$ of apyrexia and clinical recovery irrespective of the neutrophil count (134). This clinical approach showed to reduce unnecessary exposure to antimicrobials and to be safe.

\section{ICU Management}

The total number of patients with cancer who need ICU admission has increased dramatically over time, presently accounting for up to $15 \%$ of all admissions $(8,27-30)$. Overall mortality has also decreased and survivors achieve remission and quality of life after ICU admission, similar to non-ICU patients $(37,135)$. Some important changes in the management of critically ill cancer patients over recent decades have influenced these improved outcomes. These include the following:

a) Changes in ICU admission policies that may have favored faster admission of more candidates, leading to early treatment of organ dysfunction $(37,136)$.

b) Many so-called classic predictors of mortality (e.g., neutropenia, underlying disease, blood transfusion requirements, and second-line therapies) are no longer relevant or influence the therapeutic approach less $(32,137,138)$.

c) Improved collaboration between hematologists/oncologists and intensive care providers (137-140).

d) Improved management of sepsis in neutropenic patients, including escalation and de-escalation strategies for antimicrobial therapy, source control (e.g., catheter removal), and/or conducting surgery if indicated regardless of the presence of cytopenias (141-143).

e) Using specific therapies for selected patients with hematological cancers in ICU has also proven to be feasible and associated with significant survival benefit (144-147).

\section{CURRENT GAPS AND FUTURE RESEARCH}

Although much progress has been made in the understanding and management of sepsis in cancer patients, much is still to be done.

The increasing number of cancer patients who potentially require ICU management will necessitate a comprehensive revision of ICU admission policies. Early recognition of sepsis based on routine clinical, biochemical, and radiological signs is still inaccurate in cancer. Future diagnostic strategies must therefore incorporate newer tests with improved diagnostic performances, easier non-invasive sampling, and shorter response time. None of the currently available biomarkers have demonstrated sufficient sensitivity and/or specificity for use in clinical practice. Identifying new biomarkers reflecting host response and/or pathogen invasion may allow better differentiation of infectious from non-infectious processes and the early and safe discontinuation of antimicrobial therapy.

In addition, gaining a better understanding of the mutual interaction between cancer and sepsis, as well as the alterations in innate and adaptive immune cell functions, could lead to the development of potential therapeutic interventions. Identifying biomarkers that can accurately detect and quantify immune suppression in cancer patients with sepsis will be key to the design of immunomodulatory therapeutic strategies.

The adequacy of IEAT should be improved in cancer patients with sepsis, and efforts should be made to ensure adherence to current guidelines, with adaptation to local epidemiology where necessary. Studies should also continue to clarify the role of new antibiotics, such as ceftolozane/tazobactam and ceftazidime/avibactam, in cancer patients with sepsis, particularly when used empirically. Other novel antibiotics 
TABLE 3 | Summary of the main clinical and microbiological characteristics of the published case series and case reports on the use of ceftazidime/avibactam and ceftolozane/tazobactam in high-risk hematologic cancer patients.

\begin{tabular}{|c|c|c|c|c|c|c|c|c|}
\hline References & Study design & Number of patients & $\begin{array}{l}\text { Microorganisms } \\
\text { mechanisms of } \\
\text { resistance }\end{array}$ & Type of infections & Combination therapy & $\begin{array}{l}\text { All-cause } 30 \text {-day } \\
\text { case-fatality rate }\end{array}$ & $\begin{array}{l}\text { Recurrence/ } \\
\text { resistance } \\
\text { development }\end{array}$ & Comments \\
\hline \multicolumn{9}{|c|}{ Ceftazidime/Avibactam } \\
\hline $\begin{array}{l}\text { Castón et al. } \\
\text { (120) }\end{array}$ & $\begin{array}{l}\text { Multicenter, retrospective. } \\
\text { Patients treated with C/A } \\
\text { were compared with those } \\
\text { receiving other active } \\
\text { antibiotics }\end{array}$ & $\begin{array}{l}8 \mathrm{C} / \mathrm{A} \text { vs. } 23 \text { other } \\
\text { active antibiotics }\end{array}$ & $\begin{array}{l}\text { Carbapenemase-producing } \\
\text { Enterobacterales }(80.6 \% \mathrm{~K} \text {. } \\
\text { pneumoniae) } \\
61.3 \% \text { OXA-48, } \\
38.7 \% \text { KPC }\end{array}$ & Bacteremia & $\begin{array}{l}\text { 100\% Combinations } \\
\text { included: aminoglycosides } \\
\text { (7), carbapenems (3), } \\
\text { fosfomycin (2), tigecyclin } \\
\text { (2), and/or colistin (2) }\end{array}$ & $\begin{array}{l}25 \% \text { with C/A vs. } 52 \% \text { with } \\
\text { other active agents }\end{array}$ & None/None & $\begin{array}{l}\text { All treatment regiments were used as } \\
\text { targeted therapy } \\
77.4 \% \text { were neutropenic } \\
\text { The number of death events were too } \\
\text { small to detect significant differences }\end{array}$ \\
\hline $\begin{array}{l}\text { Metafuni et al. } \\
\text { (121) }\end{array}$ & $\begin{array}{l}\text { Case series of patients } \\
\text { presenting with persistent } \\
\text { sepsis or septic shock }\end{array}$ & 3 & $\begin{array}{l}\text { Carbapenemase-producing } \\
\text { K. pneumoniae }(n=2) \\
\text { MDR-P. aeruginosa }(n=1)\end{array}$ & Bacteremia & $\begin{array}{l}\text { 100\% Meropenem (2), } \\
\text { tigecyclin (3), colisitn (2) }\end{array}$ & $33 \%$ & None/None & $\begin{array}{l}\text { All treatment regiments were used as } \\
\text { targeted therapy } \\
\text { All patients were neutropenic }\end{array}$ \\
\hline $\begin{array}{l}\text { Hobson et al. } \\
\text { (122) }\end{array}$ & $\begin{array}{l}\text { Case report of a pediatric } \\
\text { patient }\end{array}$ & 1 & $\begin{array}{l}\text { NDM-1-producing } \\
\text { Morganella morganii }\end{array}$ & Bacteremia & Aztreonam (ATM) & 0 & None/None & $\begin{array}{l}\text { The patient was neutropenic } \\
\text { MIC for the combination of ATM }+ \text { C/A } \\
\text { was } 0.016 \mathrm{mg} / \mathrm{L}\end{array}$ \\
\hline \multicolumn{9}{|c|}{ Ceftolozane/Tazobactam } \\
\hline $\begin{array}{l}\text { Hakki and Lewis } \\
\text { (116) }\end{array}$ & Retrospective case series & $\begin{array}{l}6 \text { patients received } 7 \\
\text { cycles of } \mathrm{C} / \mathrm{T}\end{array}$ & MDR-P. aeruginosa & $\begin{array}{l}\text { Bacteremia (3), } \\
\text { Pneumonia (3), SSTI } \\
\text { (1) }\end{array}$ & None & 0 & 1 case/1 case & $\begin{array}{l}\text { Four patients }(66.6 \%) \text { were } \\
\text { neutropenic and two }(33.3 \%) \text { were } \\
\text { HSCT recipients } \\
\text { In two cases C/T was } \\
\text { initiated empirically }\end{array}$ \\
\hline $\begin{array}{l}\text { Fernández-Cruz } \\
\text { et al. (117) }\end{array}$ & $\begin{array}{l}\text { Retrospective, } \\
\text { case-control. Patients } \\
\text { treated with } \mathrm{C} / \mathrm{T} \text { were } \\
\text { compared with those } \\
\text { receiving other active } \\
\text { antibiotics }\end{array}$ & $\begin{array}{l}19 \mathrm{C} / \mathrm{T} \text { vs. } 38 \text { other } \\
\text { active antibiotics }\end{array}$ & $\begin{array}{l}\text { P. aeruginosa ( } 51.2 \% \text { were } \\
\text { MDR) }\end{array}$ & $\begin{array}{l}\text { Primary bacteremia } \\
\text { (4) Pneumonia (5), } \\
\text { perianal infection (3), } \\
\text { UTI (2), SSTI (1) }\end{array}$ & $\begin{array}{l}42 \% \text { Amikacin }+ \\
\text { levofloxacin (2), amikacin } \\
\text { (4), colistin (1), and } \\
\text { fosfomycin (1) }\end{array}$ & $\begin{array}{l}5.3 \% \text { with } \mathrm{C} / \mathrm{T} \text { vs. } 28.9 \% \\
\text { with other active agents }\end{array}$ & 3 cases/None & $\begin{array}{l}\mathrm{C} / \mathrm{T} \text { was used empirically in } 3 \text { cases, } \\
\text { and as targeted } \\
6 \text { patients had secondary bacteremia } \\
>60 \% \text { were neutropenic }\end{array}$ \\
\hline $\begin{array}{l}\text { Aitken et al. } \\
\text { (118) }\end{array}$ & $\begin{array}{l}\text { Case report of a pediatric } \\
\text { patient }\end{array}$ & 1 & MDR-P. aeruginosa & Bacteremia & $\begin{array}{l}\text { Tobramycin and } \\
\text { ciprofloxacin }\end{array}$ & 0 & None/1 & $\begin{array}{l}\text { The patient was neutropenic } \\
\text { The MlC to C/T increased from to } 6 \\
\text { to } 8 \mu \mathrm{g} / \mathrm{mL}\end{array}$ \\
\hline So et al. (119) & Case report & 1 & MDR-P. aeruginosa & Bacteremia & Tobramycin & 0 & None/1 & $\begin{array}{l}\text { The patient was neutropenic } \\
\text { Bacteremia cleared with the } \\
\text { combination of a } \\
\text { pharmacodynamically driven dose of } \\
\mathrm{C} / \mathrm{T} \text { and tobramycin with } \\
\text { resultant synergy }\end{array}$ \\
\hline
\end{tabular}

MDR, multidrug-resistant; SSTI, skin and soft tissue infection; HSCT, hematopoietic stem cell transplant; UTI, urinary tract infection. 
displaying activity against MDR-GNB are currently under clinical evaluation (e.g., imipenem/relabactam, plazomicin, cefiderocol, meropenem/vaborbactam, and eravacycline), and given time, these may improve the antibiotic armamentarium.

Finally, combining knowledge of more rigorous and thorough patient stratification and selection, strategic and careful long-term monitoring of immune function, and targeted immunomodulatory treatment could optimize clinical benefits for surviving initial sepsis.

\section{AUTHOR CONTRIBUTIONS}

CG and JC were responsible for the study conception and design. CG, AA-P, and GC performed the literature review. CG

\section{REFERENCES}

1. Singer M, Deutschman CS, Seymour CW, Shankar-Hari M, Annane D, Bauer $\mathrm{M}$, et al. The third international consensus definitions for sepsis and septic shock (sepsis-3). JAMA. (2016) 315:801-10. doi: 10.1001/jama.2016.0287

2. Shankar-Hari M, Phillips GS, Levy ML, Seymour CW, Liu VX, Deutschman CS, et al. Developing a new definition and assessing new clinical criteria for septic shock: for the third international consensus definitions for sepsis and septic shock (sepsis-3). JAMA. (2016) 315:775-87. doi: 10.1001/jama.2016.0289

3. Seymour CW, Liu VX, Iwashyna TJ, Brunkhorst FM, Rea TD, Scherag A, et al. Assessment of clinical criteria for sepsis: for the third international consensus definitions for sepsis and septic shock (sepsis-3). JAMA. (2016) 315:762-74. doi: 10.1001/jama.2016.0288

4. Coopersmith CM, Wunsch H, Fink PM, Linde-Zwirble WT, Olsen KM, Sommers MS, et al. A comparison of critical care research funding and the financial burden of critical illness in the United States. Crit Care Med. (2012) 40:1072-9. doi: 10.1097/CCM.0b013e31823c8d03

5. Martin GS, Mannino DM, Moss M. The effect of age on the development and outcome of adult sepsis. Crit Care Med. (2006) 34:15-21. doi: 10.1097/01.CCM.0000194535.82812.BA

6. Kahn JM, Le T, Angus DC, Cox CE, Hough CL, White DB, et al. The epidemiology of chronic critical illness in the United States*. Crit Care Med. (2015) 43:282-7. doi: 10.1097/CCM.0000000000000710

7. Danai PA, Moss M, Mannino DM, Martin GS. The epidemiology of sepsis in patients with malignancy. Chest. (2006) 129:143240. doi: 10.1378/chest.129.6.1432

8. Taccone FS, Artigas AA, Sprung CL, Moreno R, Sakr Y, Vincent JL. Characteristics and outcomes of cancer patients in European ICUs. Crit Care. (2009) 13:R15. doi: 10.1186/cc7713

9. Gudiol C, Carratalà J. Antibiotic resistance in cancer patients. Expert Rev Anti Infect Ther. (2014) 12:1003-16. doi: 10.1586/14787210.2014.920253

10. Liang T, Xu C, Cheng Q, Tang Y, Zeng H, Li X. Epidemiology, risk factors, and clinical outcomes of bloodstream infection due to extended-spectrum beta-lactamase-producing Escherichia coli and Klebsiella pneumoniae in hematologic malignancy: a retrospective study from central south China. Microb Drug Resist. (2020). doi: 10.1089/mdr.2020.0033. [Epub ahead of print].

11. Gudiol C, Calatayud L, Garcia-Vidal C, Lora-Tamayo J, Cisnal M, Duarte $\mathrm{R}$, et al. Bacteraemia due to extended-spectrum beta-lactamase-producing Escherichia coli (ESBL-EC) in cancer patients: clinical features, risk factors, molecular epidemiology and outcome. J Antimicrob Chemother. (2010) 65:333-41. doi: 10.1093/jac/dkp411

12. Trecarichi EM, Pagano L, Candoni A, Pastore D, Cattaneo C, Fanci R, et al. Current epidemiology and antimicrobial resistance data for bacterial bloodstream infections in patients with hematologic malignancies: an Italian multicentre prospective survey. Clin Microbiol Infect. (2015) 21:33743. doi: 10.1016/j.cmi.2014.11.022 drafted the manuscript. All authors approved the final version of the manuscript.

\section{FUNDING}

The work for this review was supported by the Plan Nacional de $I+D+i$ 2013-2016 and the Instituto de Salud Carlos III, Subdirección General de Redes y Centros de Investigación Cooperativa, Ministerio de Ciencia, Innovación y Universidades, Spanish Network for Research in Infectious Diseases (REIPI RD16/0016/ 0001), co-financed by the European Development Regional Fund A way to achieve Europe, Operative program Intelligent Growth 2014-2020.

13. Ha YE, Kang CI, Cha MK, Park SY, Wi YM, Chung DR, et al. Epidemiology and clinical outcomes of bloodstream infections caused by extendedspectrum $\beta$-lactamase-producing Escherichia coli in patients with cancer. Int J Antimicrob Agents. (2013) 42:403-9. doi: 10.1016/j.ijantimicag.2013. 07.018

14. Cattaneo C, Antoniazzi F, Casari S, Ravizzola G, Gelmi M, Pagani $\mathrm{C}$, et al. $P$. aeruginosa bloodstream infections among hematological patients: an old or new question? Ann Hematol. (2012) 91:1299304. doi: 10.1007/s00277-012-1424-3

15. Gudiol C, Albasanz-Puig A, Laporte-Amargós J, Pallarès N, Mussetti A, Ruiz-Camps I, et al. Clinical predictive model of multidrug resistance in neutropenic cancer patients with bloodstream infection due to Pseudomonas aeruginosa. Antimicrob Agents Chemother. (2020) 64:e0249419. doi: 10.1128/AAC.01521-19

16. Kern W, Roth JA, Bertz H, Götting T, Dettenkofer M, Widmer AF, et al. Contribution of specific pathogens to bloodstream infection mortality in neutropenic patients with hematologic malignancies. Results from a multicentric surveillance cohort study. Transpl Infect Dis. (2019) 21:e13186. doi: 10.1111/tid.13186

17. Averbuch D, Tridello G, Hoek J, Mikulska M, Akan H, Yanez San Segundo L, et al. Antimicrobial resistance in gram-negative rods causing bacteremia in hematopoietic stem cell transplant recipients: intercontinental prospective study of the infectious diseases working party of the european bone marrow transplantation group. Clin Infect Dis. (2017) 65:181928. doi: $10.1093 / \mathrm{cid} / \mathrm{cix} 646$

18. Satlin MJ, Cohen N, Ma KC, Gedrimaite Z, Soave R, Askin G, et al. Bacteremia due to carbapenem-resistant Enterobacteriaceae in neutropenic patients with hematologic malignancies. J Infect. (2016) 73:33645. doi: 10.1016/j.jinf.2016.07.002

19. Tofas P, Skiada A, Angelopoulou M, Sipsas N, Pavlopoulou I, Tsaousi $\mathrm{S}$, et al. Carbapenemase-producing Klebsiella pneumoniae bloodstream infections in neutropenic patients with haematological malignancies or aplastic anaemia: analysis of 50 cases. Int J Antimicrob Agents. (2016) 47:3359. doi: 10.1016/j.ijantimicag.2016.01.011

20. Micozzi A, Gentile G, Minotti C, Cartoni C, Capria S, Ballaro D, et al. Carbapenem-resistant Klebsiella pneumoniae in high-risk haematological patients: factors favouring spread, risk factors and outcome of carbapenemresistant Klebsiella pneumoniae bacteremias. BMC Infect Dis. (2017) 17:203. doi: 10.1186/s12879-017-2297-9

21. Cattaneo C, Di Blasi R, Skert C, Candoni A, Martino B, Di Renzo $\mathrm{N}$, et al. Bloodstream infections in haematological cancer patients colonized by multidrug-resistant bacteria. Ann Hematol. (2018) 97:171726. doi: 10.1007/s00277-018-3341-6

22. Trecarichi EM, Pagano L, Martino B, Candoni A, Di Blasi R, Nadali $\mathrm{G}$, et al. Bloodstream infections caused by Klebsiella pneumoniae in onco-hematological patients: clinical impact of carbapenem resistance in a multicentre prospective survey. Am J Hematol. (2016) 91:107681. doi: 10.1002/ajh.24489 
23. Martinez-Nadal G, Puerta-Alcalde P, Gudiol C, Cardozo C, Albasanz-Puig A, Marco F, et al. Inappropriate empirical antibiotic treatment in high-risk neutropenic patients with bacteremia in the era of multidrug resistance. Clin Infect Dis. (2020) 70:1068-74. doi: 10.1093/cid/ciz319

24. Bassetti M, Giacobbe DR, Robba C, Pelosi P, Vena A. Treatment of extended-spectrum $\beta$-lactamases infections: what is the current role of new $\beta$-lactams/ $\beta$-lactamase inhibitors? Curr Opin Infect Dis. (2020) 33:47481. doi: 10.1097/QCO.0000000000000685

25. Wright H, Bonomo RA, Paterson DL. New agents for the treatment of infections with Gram-negative bacteria: restoring the miracle or false dawn? Clin Microbiol Infect. (2017) 23:704-12. doi: 10.1016/j.cmi.2017.09.001

26. Angus DC, Linde-Zwirble WT, Lidicker J, Clermont G, Carcillo J, Pinsky MR. Epidemiology of severe sepsis in the United States: analysis of incidence, outcome, and associated costs of care. Crit Care Med. (2001) 29:130310. doi: 10.1097/00003246-200107000-00002

27. Soares M, Bozza FA, Azevedo LC, Silva UV, Correa TD, Colombari F, et al. Efects of organizational characteristics on outcomes and resource use in patients with cancer admitted to intensive care units. J Clin Oncol. (2016) 34:3315-24. doi: 10.1200/JCO.2016.66.9549

28. Pavon A, Binquet C, Kara F, Martinet O, Ganster F, Navellou JC, et al. Profile of the risk of death after septic shock in the present era: an epidemiologic study. Crit Care Med. (2013) 41:2600-9. doi: 10.1097/CCM.0b013e31829a6e89

29. van Vught LA, Klein Klouwenberg PM, Spitoni C, Scicluna BP, Wiewel MA, Horn J, et al. Incidence, risk factors, and attributable mortality of secondary infections in the intensive care unit after admission for sepsis. JAMA. (2016) 315:1469-79. doi: 10.1001/jama.2016.2691

30. Hensley MK, Donnelly JP, Carlton EE, Prescott HC. Epidemiology and outcomes of cancer-related versus non-cancer-related sepsis hospitalizations. Crit Care Med. (2019) 47:1310-6. doi: 10.1097/CCM.0000000000003896

31. Rosolem MM, Rabello LS, Lisboa T, Caruso P, Costa RT, Leal JVR, et al. Critically ill patients with cancer and sepsis: clinical course and prognostic factors. J Crit Care. (2012) 27:301-7. doi: 10.1016/j.jcrc.2011.06.014

32. Soares M, Caruso P, Silva E, Teles JMM, Lobo SMA, et al. Characteristics and outocomes of patients with cancer requiring admission to intensive care units: a prospective multicenter study. Crit Care Med. (2010) 38:915. doi: 10.1097/CCM.0b013e3181c0349e

33. Pène F, Percheron S, Lemiale V, Viallon V, Claessens YE, Marqué S, et al. Temporal changes in management and outcome of septic shock in patients with malignancies in the intensive care unit. Crit Care Med. (2008) 36:6906. doi: 10.1097/CCM.0B013E318165314B

34. Zuber B, Tran TC, Aegerter P, Grimaldi D, Charpentier J, Guidet B, et al. Impact of case volume on survival of septic shock in patients with malignancies. Crit Care Med. (2012) 40:55-62. doi: 10.1097/CCM.0b013e31822d74ba

35. Legrand M, Max A, Peigne V, Mariotte E, Canet E, Debrumetz A, et al. Survival in neutropenic patients with severe sepsis or septic shock. Crit Care Med. (2012) 40:43-9. doi: 10.1097/CCM.0b013e31822 b50c2

36. Lemiale V, Pons S, Mirouse A, Tudesq JJ, Hourmant Y, Mokart D, et al. Sepsis and septic shock in patients with malignancies: a groupe de recherche respiratoire en reanimation oncohematologique study. Crit Care Med. (2020) 48:822-9. doi: 10.1097/CCM.0000000000004322

37. Azoulay E, Mokart D, Pène F, Lambert J, Kouatchet A, Mayaux J, et al. Outcomes of critically ill patients with hematologic malignancies: prospective multicenter data from France and Belgium-a groupe de recherche respiratoire en réanimation onco-hématologique study. J Clin Oncol. (2013) 31:2810-8. doi: 10.1200/JCO.2012.47.2365

38. Ostermann M, Ferrando-Vivas P, Gore C, Power S, Harrison D. Characteristics and outcome of cancer patients admitted to the ICU in England, Wales, and Northern Ireland and National trends between 1997 and 2013. Crit Care Med. (2017) 45:1668-76. doi: 10.1097/CCM.0000000000002589

39. Daviau F, Grimaldi D, Dechartres A, Charpentier J, Geri G, Marin N, et al. Timing and causes of death in septic shock. Ann Intensive Care. (2015) 5:16. doi: 10.1186/s13613-015-0058-8

40. Jamme M, Daviaud F, Charpentier J, Marin N, Thy M, Hourmant $\mathrm{Y}$, et al. Time course of septic shock in immunocompromised and nonimmunocompromised patients. Crit Care Med. (2017) 45:20319. doi: 10.1097/CCM.0000000000002722

41. Soares M, Bozza FA, Angus DC, Japiassú AM, Viana WN, Costa R, et al. Organizational characteristics, outcomes, and resource use in 78 Brazilian intensive care units: the ORCHESTRA study. Intensive Care Med. (2015) 41:2149-60. doi: 10.1007/s00134-015-4076-7

42. Lee DS, Suh GY, Ryu JA, Chung CR, Yang JH, Park CM, et al. Effect of early intervention on long-term outcomes of critically ill cancer patients admitted to ICUs. Crit Care Med. (2015) 43:143948. doi: 10.1097/CCM.0000000000000989

43. Borcoman E, Dupont A, Mariotte E, Doucet L, Joseph A, Chermak A, et al. One-year survival in patients with solid tumours discharged alive from the intensive care unit after unplanned admission: a retrospective study. J Crit Care. (2020) 57:36-41. doi: 10.1016/j.jcrc.2020.01.027

44. Tavares M, Lemiale V, Mokart D, Pène F, Lengliné E, Kouatchet $A$, et al. Determinants of 1-year survival in critically ill acute leukemia patients: a GRRR-OH study. Leuk Lymphoma. (2018) 59:1323-31. doi: 10.1080/10428194.2017.1375106

45. Camou F, Didier M, Leguay T, Milpied N, Daste A, Ravaud A, et al. Longterm prognosis of septic shock in cancer patients. Support Care Cancer. (2020) 28:1325-33. doi: 10.1007/s00520-019-04937-4

46. Boomer JS, To K, Chang KC, Takasu O, Osborne DF, Walton AH, et al. Immunosuppression in patients who die of sepsis and multiple organ failure. JAMA. (2011) 306:2594-605. doi: 10.1001/jama.2011.1829

47. Elliott D, Davidson JE, Harvey MA, Bemis-Dougherty A, Hopkins RO, Iwashyna TJ, et al. Exploring the scope of post-intensive care syndrome therapy and care: engagement of non-critical care providers and survivors in a second stakeholders meeting. Crit Care Med. (2014) 42:251826. doi: 10.1097/CCM.0000000000000525

48. Williams MD, Braun LA, Cooper LM, Johnston J, Weiss RV, Qualy RL, et al. Hospitalized cancer patients with severe sepsis: analysis of incidence, mortality, and associated costs of care. Crit Care. (2004) 8:R291R298. doi: 10.1186/cc2893

49. Roze des Ordons AL, Chan K, Mirza I, Townsend DR, Bagshaw SM. Clinical characteristics and outcomes of patients with acute myelogenous leukemia admitted to intensive care: a case-control study. BMC Cancer. (2010) 10:516. doi: 10.1186/1471-2407-10-516

50. Bodey GP, Buckley M, Sathe YS, Freireich EJ. Quantitative relationships between circulating leukocytes and infection in patients with acute leukemia. Ann Intern Med. (1966) 64:328-40. doi: 10.7326/0003-4819-64-2-328

51. Schimpff S, Satterlee W, Young VM, Serpick A. Empiric therapy with carbenicillin and gentamicin for febrile patients with cancer and granulocytopenia. $N$ Engl J Med. (1971) 284:1061-5. doi: 10.1056/NEJM197105132841904

52. Kumar G, Ahmad S, Taneja A, Patel J, Guddati AK, Nanchal R. Milwaukee initiative in critical care outcomes research group of investigators. Severe sepsis in hematopoietic stem cell transplant recipients. Crit Care Med. (2015) 43:411-21. doi: 10.1097/CCM.0000000000000714

53. Gudiol C, Aguado J, Carratalà J. Bloodstream infections in patients with solid tumors. Virulence. (2016) 7:298-308. doi: 10.1080/21505594.2016.1141161

54. Sierra J, Díaz MV, de Jesús García M, Finello M, Suasnabar DF, Richetta L, et al. Bloodstream infections in cancer patients. Medicina. (2020) 80:329-38.

55. Guarana M, Nucci M, Nouér SA. Shock and early death in hematologic patients with febrile neutropenia. Antimicrob Agents Chemother. (2019) 63:e0125019. doi: 10.1128/AAC.01250-19

56. Delano MJ, Ward PA. The immune system's role in sepsis progression, resolution and long-term outcome. Immunol Rev. (2016) 274:33053. doi: 10.1111/imr.12499

57. Delano MJ, Ward PA. Sepsis-induced immunre dysfunction: can immune therapies reduce mortality? J Clin Invest. (2016) 126:23-31. doi: 10.1172/JCI82224

58. Rittirsch D, Flierl MA, Ward PA. Harmful molecular mechanisms in sepsis. Nat Rev Immunol. (2008) 8:776-87. doi: 10.1038/nri2402

59. Bosmann M, Ward PA. The inflammatory response in sepsis. Trends Immunol. (2013) 34:129-36. doi: 10.1016/j.it.2012.09.004

60. Huber-Lang MS, Sarma JV, McGuire SR, Lu KT, Guo RF, Padgaonkar VA, et al. Protective effects of anti-C5a peptide antibodies in experimental sepsis. FASEB J. (2001) 15:568-70. doi: 10.1096/fj.00-0653fje 
61. Santos SS, Brunialti MK, Rigato O, Machaado FR, Silva E, Salomao R. Generation of nitric oxide and reactive oxygen species by neutrophils and monocytes from septic patients and association with outcomes. Shock. (2012) 38:18-23. doi: 10.1097/SHK.0b013e318257114e

62. Brealey D, Brand M, Hargreaves I, Heales S, Land J, Smolenski $\mathrm{R}$, et al. Association between mitochondrial dysfunction and severity and outcome of septic shock. Lancet. (2002) 360:21923. doi: 10.1016/S0140-6736(02)09459-X

63. Mendonça MA, Cunha FQ, Murta EF, Tavares-Murta BM. Failure of neutrophil chemotactic function in breats cancer patients treated with chemotherapy. Cancer Chemother Pharmacol. (2006) 57:663-70. doi: 10.1007/s00280-005-0086-4

64. García Muñoz R, Izquierdo-Gil A, Muñoz A, Roldan-Galiacho V, Rabasa P, Panizo C. Lymphocyte recovery is impaied in patients with chronic lymphocytic leukemia and indolent non-Hodgkin lymphomas treated with bendamustine plus rituximab. Ann Hematol. (2014) 93:187987. doi: $10.1007 / \mathrm{s} 00277-014-2135-8$

65. Bosch M, Khan FM, Storek J. Immune reconstitution after hematopoietic stem cell transplantation. Curr Opin Hematol. (2012) 19:324-35. doi: 10.1097/MOH.0b013e328353bc7d

66. Karvunidis T, Chvojka J, Lysak D, Sykora R, Krouzecky A, Radej J, et al. Septic shock and chemotherapy-induced cytopenia: effects on microcirculation. Intensive Care Med. (2012) 38:1336-44. doi: 10.1007/s00134-012-2582-4

67. Toma A, Fenaux P, Dreyfus F, Cordonnier C. Infections in myelodysplastic síndromes. Haematologica. (2012) 97:145970. doi: 10.3324/haematol.2012.063420

68. Schreiber RD, Old LJ, Smyth MJ. Cancer immunoediting: integrating immunity's roles in cancer suppression and promotion. Science. (2011) 331:1565-70. doi: 10.1126/science.1203486

69. Contou D, Roux D, Jochmans S, Coudroy R, Guérot E, Grimaldi D, et al. Septic shock with no diagnosis at 24 hours: a pragmatic multicenter prospective cohort study. Crit Care. (2016) 20:360. doi: 10.1186/s13054-016-1537-5

70. Moreau AS, Lengline E, Seguin A, Lemiale V, Canet E, Raffoux E, et al. Respiratory events at the earliest phase of acute myeloid leukemia. Leuk Lymphoma. (2014) 55:2556-63. doi: 10.3109/10428194.2014.887709

71. Cherrualut M, Le Goff M, Tamburini J, Pène F. Urgent chemotherapy in sepsis-like shock related to hematologic malignancies. Crit Care Med. (2018) 46:e465-e468. doi: 10.1097/CCM.0000000000002990

72. Brudno JN, Kochenderfer JN. Toxicities of chimeric antigen receptor $\mathrm{T}$ cells: recognition and management. Blood. (2016) 127:3321-30. doi: 10.1182/blood-2016-04-703751

73. Montesinos P, Bergua JM, Vellenga E, Rayón C, Parody R, De la Serna J, et al. Differentitation syndrome in patients with acute promyelocytic leukemia treated with all-transretinoic acid and anthracycline chemotherapy: characteristics, outcome, and prognostic factors. Blood. (2009) 113:77583. doi: 10.1182/blood-2008-07-168617

74. Liu Z, Mahale P, Engels EA. Sepsis and risk of cancer among elderly adults in the United States. Clin Infect Dis. (2018) 68:717-24. doi: 10.1093/ci d/ciy530

75. Kristinsson SY, Bjorkholm M, Hultcrantz M, Derolf AR, Landgren O, Goldin R. Chronic imjne stimulation might act as a trigger for the development of acute myeloid leukemia or myelodysplastic síndromes. J Clin Oncol. (2011) 29:2897-903. doi: 10.1200/JCO.2011.34.8540

76. Cavassani KA, Carson WF, Moreira AP, Wen H, Schaller MA, Ishii M, et al. The post sepsis-induced expansion and enhanced function of regulatory $\mathrm{T}$ cells create an enviroment to potentiate tumor growth. Blood. (2010) 115:4403-11. doi: 10.1182/blood-2009-09-241083

77. Mota JM, Leite CA, Souza E, Melo PH, Nascimento DC, deDeus-Wagatsuma VM, et al. Post-sepsis State induces tumorassociated macrophage accumulation through CXCR4/CXCL12 and favors tumor progression in mice. Cancer Inmunol Res. (2016) 4:312-22. doi: 10.1158/2326-6066.CIR-15-0170

78. Maywald O, Buchheidt D, Bergmann J, Schoch C, Ludwig WD, Reiter A, et al. Spontaneous remission in adult acute myeloid leukemia in association with systemic bacterial infection-case report and review of the literature. Ann Hematol. (2004) 83:189-94. doi: 10.1007/s00277-00 3-0741-y
79. Bowles AP Jr, Perkins E. Long-term remission of malignant brain tumors after intracranial infection: a report of four cases. Neurosurgery. (1999) 44:636-42. doi: 10.1097/00006123-199903000-00110

80. Buzas K, Marton A, Vizler C, Gyukity-Sebestyén E, Harmati M, Nagy K, et al. Bacterial sepsis increases survival in metastatic melanoma: Chlamydophila pneumoniae induces macrophage polarization and tumor regression. J Invest Dermatol. (2016) 136:862-5. doi: 10.1016/j.jid.2015.12.032

81. Danahy DB, Jensen IJ, Griffith TS, Badovinac VP. Cutting edge: polymicrobial sepsis has the capacity to reinvigorate tumor-infiltrating CD8 T cells and prolong host survival. J Immunol. (2019) 202:28438. doi: 10.4049/jimmunol.1900076

82. Vigneron CA, Mirouse H, Merdji H, Rousseau C, Cousin C, Alby-Laurent F, et al. Sepsis inhibits tumor growth in mice with cancer through Toll-like receptor 4-associated enhanced Natural Killer cell activity. Oncoimmunology. (2019) 8:e1641391. doi: 10.1080/2162402X.2019.1641391

83. Viaud S, Saccheri F, Mignot G, Yamazaki T, Daillère R, Hannani D, et al. The intestinal microbiota modulates the anticancer immune effects of cyclophosphamide. Science. (2013) 342:971-6. doi: 10.1126/science.1240537

84. Iida N, Dzutsev A, Stewart CA, Smith L, Bouladoux N, Weingarten $\mathrm{RA}$, et al. Commensal bacteria control cancer response to therapy by modulating the tumor microenvironment. Science. (2013) 342:96770. doi: 10.1126/science.1240527

85. Apetoh L, Ghiringhelli F, Tesniere A, Obeid M, Ortiz C, Criollo A, et al. Toll-like receptor 4-dependent contribution of the immune system to anticancer chemotherapy and radiotherapy. Nat Med. (2007) 13:10509. doi: $10.1038 / \mathrm{nm} 1622$

86. Feng $\mathrm{Y}, \mathrm{Mu} \mathrm{R}$, Wang $\mathrm{Z}$, Xing $\mathrm{P}$, Zhang J, Dong $\mathrm{L}$, et al. A tolllike receptor agonist mimicking microbial signal to generate tumor-suppressive macrophages. Nat Commun. (2019) 10:2272. doi: 10.1038/s41467-019-10354-2

87. Torres VB, Azevedo LC, Silva UV, Caruso P, Torelly AP, Eliezer S, et al. Sepsis-associated outcomes in critically ill patients with malignancies. Ann Am Thorac Soc. (2015) 12:1185-92. doi: 10.1513/AnnalsATS.20150 1-046OC

88. Yoo J, Jung Y, Ahn JH, Choi YJ, Lee KH, Hur S. Incidence and clinical course of sèptic shock in neutropenic patients during chemtherapy for gynecological cancers. J Gynecol Oncol. (2020) 31:e62. doi: 10.3802/jgo.2020.31.e62

89. Marín M, Gudiol C, Castet F, Oliva M, Peiró I, Royo-Cebrecos C, et al. Bloodstream infection in patients with head and neck cancer: a major challenge in the cetuximab era. Clin Transl Oncol. (2019) 21:18796. doi: 10.1007/s12094-018-1905-5

90. Peyrony O, Gerlier C, Barla I, Ellouze S, Legay L, Azoulay E, et al. Antibiotic prescribing and outcomes in cancer patients with febrile neutropenia in the emergency department. PLoS ONE. (2020) 15:e0229828. doi: 10.1371/journal.pone.0229828

91. Trecarichi EM, Tumbarello M, Spanu T, Caira M, Fianchi L, Chiusolo P, et al. Incidence and clinical impact of extended-spectrum-beta-lactamase (ESBL) production and fluoroquinolone resistance in bloodstream infections caused by Escherichia coli in patients with hematological malignancies. I Infect. (2009) 58:299-307. doi: 10.1016/j.jinf.2009.02.002

92. Gudiol C, Tubau F, Calatayud L, Garcia-Vidal C, Cisnal M, Sánchez-Ortega I, et al. Bacteraemia due to multidrug-resistant gram-negative bacilli in cancer patients: risk factors, antibiotic therapy and outcomes. J Antimicrob Chemother. (2011) 66:657-63. doi: 10.1093/jac/dkq494

93. Kadri SS, Lai YL, Warner S, Strich JR, Babiker A, Ricotta EE, et al. Inappropriate empirical antibiotic therapy for bloodstream infections based on discordant in-vitro susceptibilities: a retrospective cohort analysis of prevalence, predictors, and mortality risk in US hospitals. Lancet infect Dis. (2020) 21:241-51. doi: 10.1016/S1473-3099(20)30477-1

94. Marín M, Gudiol C, Ardanuy C, Garcia-Vidal C, Jimenez L, DomingoDomenech E, et al. Factors influencing mortality in neutropenic patients with haematologic malignancies or solid tumours with bloodstream infection. Clin Microbiol Infect. (2015) 21:583-90. doi: 10.1016/j.cmi.20 15.01.029

95. Rhodes A, Evans LE, Alhazzani W, Levy MM, Antonelli M, Ferrer R, et al. Surviving sepsis campaign: international guidelines for management of sepsis and septic shock: 2016. Intensive Care Med. (2017) 43:30477. doi: $10.1007 / \mathrm{s} 00134-017-4683-6$ 
96. Vincent JL, Moreno R, Takala J, Willatts S, De Mendonça A, Bruining H, et al. The SOFA (sepsis-related organ failure assessment) score to describe organ dysfunction/failure. On behalf of the working group on sepsis-related problems of the european society of intensive care medicine. Intensive Care Med. (1996) 22:707-10. doi: 10.1007/BF01709751

97. Nathan N, Sculier JP, Ameye L, Paesmans M, Bogdan-Dragos G, Meert AP. Sepsis and septic shock definitions in patients with cancer admitted in iCU. J Intensive Care Med. (2019) 23:885066619894933. doi: 10.1177/0885066619894933

98. Koh TL, Canet E, Amjad S, Bellomo R, Taylor D, Gan HK, et al. Prognostic performance of qSOFA in oncology patients admitted to the emergency department with suspected infection. Asia Pac J Clin Oncol. (2020) 17:94100. doi: 10.1111/ajco.13422

99. Lappalainene M, Hämäläinen S, Romppanen T, Pulkki K, Pyöräl M, Koivula $\mathrm{I}$, et al. Febrile neutropenia in patients with acute myeloid leukemia: outcome in relation to qSOFA score, C-reactive protein, and blood culture findings. Eur J Haematol. (2020) 105:731-40. doi: 10.1111/ejh.13500

100. Pierrakos C, Vincent JL. Sepsis biomarkers: a review. Crit Care. (2010) 14:R15. doi: 10.1186/cc8872

101. Wu CW, Wu JY, Chen CK, Huang SL, Hsu SC, Gabriel Lee MT, et al. Does procalcitonin, C-reactive protein, or interleukin- 6 test have a role in the diganosis of severe infection in patients with febrile neutropenia? A systematic review and meta-analysis. Support Care Cancer. (2015) 23:286372. doi: 10.1007/s00520-015-2650-8

102. Yang M, Choi SJ, Lee J, Lee DG, Kim YJ, Park YJ, et al. Serum procalcitonin as an independent diagnostic markers of bacteremia in febrile patients with hematologic malignancies. PLoS ONE. (2019) 14:e0225765. doi: 10.1371/journal.pone.0225765

103. Shilpakar R, Paudel BD, Neupane P, Shah A, Acharya B, Dulal S, et al. Procalcitonin and C-reactive protein as markers of bacteremia in patients with febrile neutropenia who receive chemotherapy for acute leukemia: a prospective study from Nepal. J Glob Oncol. (2019) 5:16. doi: 10.1200/JGO.19.00147

104. Blouin AG, Hsu M, Fleisher M, Ramanathan LV, Pastores SM. Utility of procalcitonin as a predictor of bloodstream infections and supportive modality requirements in critically ill cancer patients. Clin Chim Acta. (2020) 510:181-5. doi: 10.1016/j.cca.2020.07.024

105. Prat C, Sancho JM, Dominguez J, Xicoy B, Gimenez M, Ferra C, et al. Evaluation of procalcitonin, neopterin, C-reactive protein, IL-6 and IL- 8 as a diagnostic marker of infection in patients with febrile neutropenia. Leuk Lymphoma. (2008) 49:1752-61. doi: 10.1080/10428190802258956

106. Juutilainen A, Hämäläinen S, Pulkki K, Kuittinen T, Nousiainen T, Jantunen E, et al. Biomarkers for bacteremia andsevere sepsis in hematological patients with neutropenic fever: multivariate logistic regression analysis and factor analysis. Leuk Lymphoma. (2011) 52:2349-55. doi: 10.3109/10428194.2011.597904

107. Angeletti S, Spoto S, Fogolari M, Cortigiani M, Fioravanti M, De Florio $\mathrm{L}$, et al. Diagnostic and prognostic role of procalcitonin (PCT) and MRpro-adrenomedullin (MR-proADM) in bacterial infections. APMIS. (2015) 123:740-8. doi: 10.1111/apm.12406

108. Al Shuaibi M, Bahu RR, Chaftari AM, Wohoush IA, Shomali W, Jiang Y, et al. Pro-adrenomedullin as a novel biomarker for predicting infections and response to antimicrobials in febrile patients with hematologic malignancies. Clin Infect Dis. (2013) 56:943-50. doi: 10.1093/cid/cis1029

109. Debiane L, Hachem RY, Al Wohoush IA, Shomali W, Bahu RR, Jiang Y, et al. The utility of proadrenomedullin and procalcitonin in comparison to C-reactive protein as predictors of sepsis and bloodstream infections in critically ill patients with cancer*. Crit Care Med. (2014) 42:25007. doi: 10.1097/CCM.0000000000000526

110. Kostic I, Gurrieri C, Piva E, Semenzato G, Plebani M, Caputo I, et al. Comparison of presepsin, procalcitonin, interleukin- 8 and c-reactive protein in predicting bacteraemia in febrile neutropenic adult patients with haematological malignancies. Mediterr J Hematol Infect Dis. (2019) 11:e2019047. doi: 10.4084/mjhid.2019.047

111. Averbuch D, Orasch C, Cordonnier C, Livermore DM, Mikulska M, Viscoli $\mathrm{C}$, et al. European guidelines for emperical antibacterial therapy for febrile neutropenic patients in the era of growing resistance. Haematologica. (2013) 98:1826. doi: 10.3324/haematol.2013.091025
112. Paul M, Lador A, Grozinsky-Glasberg S, Leibovici L. Beta lactam antibiotic monotherapy versus beta lactam-aminoglycoside antibiotic combination therapy for sepsis. Cochrane database Syst Rev. (2014) 2014:CD003344. doi: 10.1002/14651858.CD003344.pub3

113. Ong DSY, Frencken JF, Klein Klouwenberg PMC, Juffermans N, Van der Poll T, Bonten MJM, et al. Short-course adjunctive gentamicin as empirical therapy in patients with severe sepsis and septic shock: a prospective observational cohort study. Clin Infect Dis. (2017) 64:17316. doi: 10.1093/cid/cix186

114. Martínez JA, Cobos-Trigueros N, Soriano A, Almela M, Ortega M, Marco $F$, et al. Influence of empiric therapy with a $\beta$-lactam alone or combined with an aminoglycoside on prognosis of bacteremia due to gramnegative microorganisms. Antimicrob Agents Chemother. (2010) 54:35906. doi: 10.1128/AAC.00115-10

115. Kumar A, Zarychanski R, Light B, Parrillo J, Maki D, Simon D, et al. Early combination antibiotic therapy yields improved survival compared with monotherapy in septic shock: a propensity-matched analysis. Crit Care Med. (2010) 38:1773-85. doi: 10.1097/CCM.0b013e3181eb3ccd

116. Hakki M, Lewis JS II. Ceftolozane-tazobactam therapy for multidrugresistant Pseudomonas aeruginosa infections in patients with hematologic malignancies and hematopoietic-cell transplant recipients. Infection. (2018) 46:431-4. doi: 10.1007/s15010-018-1125-5

117. Fernández-Cruz A, Alba N, Semiglia-Chong MA, Padilla B, RodríguezMacías G, Kwon M, et al. A case-control study of real-life experience with ceftolozane-tazobactam in patients with hematologic malignancy and Pseudomonas aeruginosa infection. Antimicrob Agents Chemother. (2019) 63:e02340-e02318. doi: 10.1128/AAC.02340-18

118. Aitken SL, Kontoyiannis DP, DePombo AM, Bhatti MM, Tverdek FP, Gettys SC, et al. Use of ceftolozane/tazobactam in the treatment of multidrug-resistant Pseudomonas aeruginosa bloodstream infection in a pediatric leukemia patient. Pediatr Infect Dis J. (2016) 35:10402. doi: 10.1097/INF.0000000000001228

119. So W, Shurko J, Galega R, Quilitz R, Greene JN, Lee GC. Mechanisms of high-level ceftolozane/tazobactam resistance in Pseudomonas aeruginosa from a severely neutropenic patient and treatment success from synergy with tobramycin. J Antimicrob Chemother. (2019) 74:269-71. doi: 10.1093/jac/dky393

120. Castón JJ, Lacort-Peralta I, Martín-Dávila P, Loeches B, Tabares S, Temkin $\mathrm{L}$, et al. Clinical efficacy of ceftazidime/avibactam versus other active agents for the treatment of bacteremia due to carbapenemase-producing Enterobacteriaceae in hematologic patients. Int J Infect Dis. (2017) 59:11823. doi: 10.1016/j.ijid.2017.03.021

121. Metafuni E, Criscuolo M, Spanu T, Sica S. Ceftazidime-avibactam for gram-negative multidrug-resistant bacteria in hematological patients: a single-center experience. Ann Hematol. (2019) 98:1495-7. doi: 10.1007/s00277-018-3535-y

122. Hobson CA, Bonacorsi S, Fahd M, Baruchel A, Cointe A, Poey N, et al. Successful treatment of bacteremia due to NDM-1-producing morganella morganii with aztreonam and ceftazidime-avibactam combination in a pediatric patient with hematologic malignancy. Antimicrob Agents Chemother. (2019) 63:e02463-18. doi: 10.1128/AAC.02463-18

123. Roberts JA, Webb S, Paterson D, Ho KM, Lipman J. A systematic review on clinical benefits of continuous administration of beta-lactam antibiotics. J Crit Care Med. (2009) 37:2071-8. doi: 10.1097/CCM.0b013e3181 a0054d

124. Roberts JA, Abdul-Aziz MH, Davis JS, Dulhunty JM, Cotta MO, Myburgh $J$, et al. Continuous versus intermittent $\beta$-lactam infusion in severe sepsis: a meta-analysis of individual patient data from randomized trials. Am J Respir Crit Care Med. (2016) 194:681-91. doi: 10.1164/rccm.201601$0024 \mathrm{OC}$

125. Vardakas KZ, Voulgaris GL, Maliaros A, Samonis G, Falagas ME. Prolonged versus short-term intravenous infusion of antipseudomonal $\beta$-lactams for patients with sepsis: a systematic review and meta-analysis of randomised trials. Lancet Infect Dis. (2018) 18:108-20. doi: 10.1016/S1473-3099(17)30615-1

126. Abbott IJ, Roberts JA. Infusional beta-lactam antibiotics in febrile neutropenia: has the time come? Curr Opin Infect Dis. (2012) 25:61925. doi: $10.1097 / Q C O .0 b 013 e 32835915 c 2$ 
127. Gonçalves-Pereira J, Póvoa P. Antibiotics in critically ill patients: a systematic review of the pharmacokinetics of $\beta$-lactams. Crit Care. (2011) 15:R206. doi: 10.1186/cc10441

128. Pea F, Viale P, Damiani D, Pavan F, Cristini F, Fanin R, et al. Ceftazidime in acute myeloid leukemia patients with febrile neutropenia: helpfulness of continuous intravenous infusion in maximizing pharmacodynamic exposure. Antimicrob Agents Chemother. (2005) 49:3550-3. doi: 10.1128/AAC.49.8.3550-3553.2005

129. Wrenn RH, Cluck D, Kennedy L, Ohl C, Williamson JC. Extended infusion compared to standard infusion cefepime as empiric treatment of febrile neutropenia. J Oncol Pharm Pract. (2018) 24:170-5. doi: 10.1177/1078155216687151

130. Fehér C, Rovira M, Soriano A, Esteve E, Martínez JA, Marco F, et al. Effect of meropenem administration in extended infusion on the clinical outcome of febrile neutropenia: a retrospective observational study. J Antimicrob Chemother. (2014) 69:2556-62. doi: 10.1093/jac/dku150

131. Ram R, Halavy Y, Amit O, Paran Y, Katchman E, Yachini B, et al. Extended versus bolus infusion of broad spectrum $\beta$-lactams for febrile neutropenia: an unblinded randomized trial running title: $\beta$-lactam infusion in febrile neutropenia. Clin Infect Dis. (2018) 67:1153-60. doi: 10.1093/cid/ciy258

132. Gudiol C, Laporte J, Albasanz-Puig A, Sánchez-Ortega I, Cuervo G, Carratalà J. Extended infusion of broad-spectrum $\beta$-lactams in high-risk febrile neutropenic patients. Clin Infect Dis. (2019) 68:890. doi: 10.1093/cid/ciy783

133. Laporte-Amargos J, Gudiol C, Arnan M, Puerta-Alcalde P, Carmona-Torre $F$, Huguet $M$, et al. Efficacy of extended infusion of $\beta$-lactam antibiotics for the treatment of febrile neutropenia in haematologic patients: protocol for a randomised, multicentre, open-label, superiority clinical trial (BEATLE). Trials. (2020) 21:412. doi: 10.1186/s13063-020-04323-0

134. Aguilar-Guisado M, Espigado I, Martín-Peña A, Gudiol C, Royo-Cebrecos C, Falantes F, et al. Optimisation of empirical antimicrobial therapy in patients with haematological malignancies and febrile neutropenia (how long study): an open-label, randomised, controlled phase 4 trial. Lancet Haematol. (2017) 4:e573-83. doi: 10.1016/S2352-3026(17)30211-9

135. Schellongowski P, Staudinger T, Kundi M, Laczika K, Locker GJ, Bojic A, et al. Prognostic factors for intensive care unit admission, intensive care outcome, and post-intensive care survival in patients with de novo acute myeloid leukemia: a single center experience. Haematologica. (2011) 96:2317. doi: 10.3324/haematol.2010.031583

136. Martos-Benítez FD, Soto-García A, Gutiérrez-Noyolam A. Clinical characteristics and outcomes of cancer patients requiring intensive care unit admission: a prospective study. J Cancer Res Clin Oncol. (2018) 144:717-23. doi: 10.1007/s00432-018-2581-0

137. Azoulay E, Pene F, Darmon M, Lengliné E, Benoit D, Soares M, et al. Managing critically ill hematology patients: time to think differently. Blood Rev. (2015) 29:359-67. doi: 10.1016/j.blre.201 5.04 .002

138. Azoulay E, Soares M, Darmon M, Benoit D, Pastores S, Afessa B. Intensive care of the cancer patient: recent achievements and remaining challenges. Ann Intensive Care. (2011) 1:5. doi: 10.1186/21105820-1-5
139. Peigne V, Rusinova K, Karlin L, Darmon M, Fermand JP, Schlemmer B, et al. Continued survival gains in recent years among critically ill myeloma patients. Intensive Care Med. (2009) 35:512-8. doi: 10.1007/s00134-008-1320-4

140. Azoulay E, Recher C, Alberti C, Soufir L, Leleu G, Le Gall JR, et al. Changing use of intensive care for hematological patients: the example of multiple myeloma. Intensive Care Med. (1999) 25:1395401. doi: 10.1007/s001340051087

141. Mokart D, Darmon M, Resche-Rigon M, Lemiale V, Pène F, Mayaux J, et al. Prognosis of neutropenic patients admitted to the intensive care unit. Intensive Care Med. (2015) 41:296-303. doi: 10.1007/s00134-014-3615-y

142. Sachak T, Arnold MA, Naini BV, Graham RP, Shah SS, Cruise M, et al. Neutropenic enterocolitis: new insights into a deadly entity. Am J Surg Pathol. (2015) 39:1635-42. doi: 10.1097/PAS.0000000000000517

143. Mokart D, Slehofer G, Lambert J, Sannini A, Chow-Chine L, Brun JP, et al. De-escalation of antimicrobial treatment in neutropenic patients with severe sepsis: results from an observational study. Intensive Care Med. (2014) 40:41-9. doi: 10.1007/s00134-013-3148-9

144. Benoit DD, Depuydt PO, Vandewoude KH, Offner FC, Boterberg T, de Cock $\mathrm{CA}$, et al. Outcome in severely ill patients with hematological malignancies who received intravenous chemotherapy in the intensive care unit. Intensive Care Med. (2006) 32:93-9. doi: 10.1007/s00134-005-2836-5

145. Wohlfarth P, Staudinger T, Sperr WR, Bojic A, Robak O, Hermann A, et al. Prognostic factors, long-term survival, and outcome of cancer patients receiving chemotherapy in the intensive care unit. Ann Hematol. (2014) 93:1629-36. doi: 10.1007/s00277-014-2141-x

146. Darmon M, Thiery G, Ciroldi M, de Miranda S, Galicier L, Raffoux $\mathrm{E}$, et al. Intensive care in patients with newly diagnosed malignancies and a need for cancer chemotherapy. Crit Care Med. (2005) 33:248893. doi: 10.1097/01.CCM.0000181728.13354.0A

147. Leprêtre P, Clavier T, Ménard AL, Grange S, Girault C, Boyer D. Rescue stem cell allograft in intensive care unit patients during septic shock with multiorgan failure. J Crit Care. (2019) 54:122-4. doi: 10.1016/j.jcrc.2019.07.002

Conflict of Interest: CG has served as speaker at scientific meetings sponsored by Pfizer and MSD. GC has participated as speaker at scientific meetings sponsored by Pfizer. JC has participated as speaker at scientific meetings sponsored by Pfizer and MSD.

The remaining author declares that the research was conducted in the absence of any commercial or financial relationships that could be construed as a potential conflict of interest.

Copyright (C) 2021 Gudiol, Albasanz-Puig, Cuervo and Carratalà. This is an openaccess article distributed under the terms of the Creative Commons Attribution License (CC BY). The use, distribution or reproduction in other forums is permitted, provided the original author(s) and the copyright owner(s) are credited and that the original publication in this journal is cited, in accordance with accepted academic practice. No use, distribution or reproduction is permitted which does not comply with these terms. 